\title{
Serum lipoproteins in day and shift workers: a prospective study
}

\author{
A Knutson, $\mathrm{H}$ Andersson, $\mathrm{U}$ Berglund
}

\begin{abstract}
This study was designed to assess changes in diet and serum lipoproteins in shift workers. Twelve shift workers and 13 day workers were examined before employment and after six months at work. Total cholesterol and serum triglycerides did not change significantly. In both groups a decrease in systolic blood pressure was observed. The ratio between apoB and apoA-1 lipoproteins increased by $18 \%$ in shift workers compared with $5 \%$ in day workers. The change in the ratio between apoB and apoA-1 lipoproteins showed a significant inverse correlation with the change in intake of dietary fibres.
\end{abstract}

Recent studies have indicated that shift work is associated with an increased risk of coronary heart disease (CHD). ${ }^{1-4}$ Few studies exist, however, of traditional risk factors for CHD in shift workers. Some have shown lipoprotein disturbances in shift workers but those did not include dietary data. ${ }^{5-7}$ One likely reason for increased levels of blood lipids in shift workers might be their dietary habits but there are no data available to support this assumption.

The present study had two aims: to determine whether shift work results in disturbances of serum lipoproteins and to determine whether dietary factors are related to changes in serum lipoproteins.

\section{Material and methods}

Workers who had applied for a job at a paper mill and a machine manufacturing plant were invited to participate in the study. The first examination was carried out the week before employment started and the second six months later.

Those who met the following criteria were included in the study: men between the ages of 18 and 39 with normal concentrations of serum cholesterol $(<7.0 \mathrm{mmol} / \mathrm{l})$ and serum triglycerides $(<2.2$ $\mathrm{mmol} / \mathrm{l})$. Subjects with any of the following were

National Institute for Psychosocial Factors and Health, Stockholm, Department of Clinical Nutrition, University of Gothenburg, Sweden A Knutson, $H$ Andersson, U Berglund excluded: shift work during the previous six months; immigrants; and history of CHD, diabetes, kidney disease, or any other chronic disease.

Of the $\mathbf{4 3}$ men who were enrolled in the study, 39 subsequently participated in the follow up examination six months later. Of these, six did not qualify owing to incomplete dietary diaries. In addition, eight were excluded because of an accident in the laboratory resulted in incomplete serum analyses. Of the 25 subjects who completed both examinations, 12 were shift workers and 13 day workers.

The shift workers worked a rotating three shift schedule and were process operators. The shifts changed at 0600,1400 , and 2200 in the following sequence:

NNNN---MM-AAAM--MMMM-AAA-NNN------ $(\mathbf{N}=$ night shift, $M=$ morning shift, $A=$ afternoon shift and $-=$ day off).

The day workers were maintenance men and metalworkers. The weekly working hours for day workers were 40 and for shift workers 36 .

All subjects completed a questionnaire that included a detailed occupational history, smoking habits, and current medical symptoms. The medical examination included measurement of body weight and height. Body mass index (BMI) was calculated: BMI = body weight $/$ height $^{2}$.

Blood pressure was measured with a sphygmomanometer with the subject supine and after five minutes of rest. Venous blood samples were drawn from an arm vein in the morning after a night's sleep, the subject having fasted from 2400 the night before. Plasma was centrifuged within two hours, stored in a refrigerator at $4^{\circ} \mathrm{C}$, and analysed within three days. The analyses of blood specimens included total cholesterol, triglycerides, apolipoprotein-B (apoB), apolipoprotein-A1 (apoA-1), and $\gamma$ glutamyltransferase (GGT). Total serum cholesterol and serum triglycerides were determined by enzymatic methods. ApoB and apoA-1 in serum were determined by an immunochemical reaction. Within the range of the method the turbidity of the immunoprecipitation, measured at $340 \mathrm{~nm}$, is proportional to the concentration of apoB and apoA-1. ${ }^{89}$

Nutrient intake was assessed from a four day diary. ${ }^{1011}$ The study subjects were instructed to record everything they ate and drank during four consecutive days. Each food item was recorded in 
detail, whether bread was white, brown, or wholemeal, whether meat was fatty or lean, roasted, stewed, or grilled. The individual intake of energy and nutrients was calculated from national food composition tables. ${ }^{12}$

Validation of protein intake was performed through assessment of urinary excretion of nitrogen. ${ }^{1314}$ A 24 hour urine sample was collected during one of the four days for which the dietary diary was kept. Total volumes were recorded and aliquots of the 24 hour collections were stored at $-20^{\circ} \mathrm{C}$ before analysis. Total $\mathrm{N}$ was measured by the Kjeldahl technique in an autoanalyser (Technicon).

The significance of difference in changes in the different variables was tested by Student's $t$ test and $\chi^{2}$-test as appropriate. Pearson correlation coefficients were also computed.

\section{Results}

Table 1 summarises subject characteristics at the first examination. The dietary intake of major nutrients was similar in the two groups at the first examination (table 2).

The mean protein intake in both study groups, as estimated from dietary records, was $94.6 \mathrm{~g}$ (SD 16.7) at baseline examination and $86.1 \mathrm{~g}$ (SD 20.4) at follow up. The corresponding values computed from urinary nitrogen losses were $91.0 \mathrm{~g}$ (SD 37.9) and $83 \cdot 1 \mathrm{~g}$ (SD 37.4). The correlation coefficient between protein intake assessed by dietary records and urinary nitrogen losses was $0.23(p=0.05)$.

Table 3 shows the changes in dietary intake and blood variables after six months of work. The change in the ratio between apoB and apoA-1 was significantly increased only in shift workers. When com-

Table 1 Subject characteristics in day and shift workers at baseline examination (two tailed test)

\begin{tabular}{|c|c|c|c|c|c|}
\hline & \multicolumn{2}{|c|}{$\begin{array}{l}\text { Day workers } \\
(n=13)\end{array}$} & \multicolumn{2}{|c|}{$\begin{array}{l}\text { Shift workers } \\
(n=12)\end{array}$} & \multirow[b]{2}{*}{$p$} \\
\hline & Mean & $S D$ & Mean & $S D$ & \\
\hline $\begin{array}{l}\text { Age } \\
\text { Weight (kg) } \\
\text { Height (cm) } \\
\text { BMI }\end{array}$ & $\begin{array}{r}25 \cdot 6 \\
71 \cdot 0 \\
177 \cdot 3 \\
22 \cdot 6\end{array}$ & $\begin{array}{l}6 \cdot 4 \\
8 \cdot 1 \\
5 \cdot 4 \\
2 \cdot 2\end{array}$ & $\begin{array}{r}21 \cdot 0 \\
78 \cdot 5 \\
179 \cdot 1 \\
24 \cdot 5\end{array}$ & $\begin{array}{l}4 \cdot 4 \\
9 \cdot 6 \\
6 \cdot 8 \\
3 \cdot 3\end{array}$ & $\begin{array}{l}0.05 \\
0.05 \\
\text { NS } \\
0.05\end{array}$ \\
\hline $\begin{array}{l}\text { Systolic blood } \\
\text { pressure } \\
\text { Diastolic blood }\end{array}$ & 124 & 10 & 132 & 13 & 0.05 \\
\hline $\begin{array}{l}\text { pressure } \\
\text { Smokers } \\
\text { Cholesterol (mmol/l) } \\
\text { Triglycerides }\end{array}$ & $\begin{array}{l}68 \\
2(15 \%) \\
5.0\end{array}$ & )$_{0.9}^{8}$ & $\begin{array}{l}71 \\
1(8 \%) \\
4.0\end{array}$ & $0_{0 \cdot 6}^{11}$ & $\begin{array}{l}\text { NS } \\
\text { NS } \\
0.01\end{array}$ \\
\hline $\begin{array}{c}(\mathrm{mmol} / \mathrm{l}) \\
\text { apoB }(\mathrm{g} / \mathrm{l}) \\
\text { apoA-1 (g/l) } \\
\text { apoB/apoA-1 } \\
\text { GGT }(\mu \mathrm{kat} / \mathrm{l})\end{array}$ & $\begin{array}{l}1.0 \\
1.03 \\
1.17 \\
0.91 \\
0.31\end{array}$ & $\begin{array}{l}0.3 \\
0 \cdot 19 \\
0 \cdot 20 \\
0 \cdot 22 \\
0 \cdot 15\end{array}$ & $\begin{array}{l}1 \cdot 0 \\
0 \cdot 84 \\
1 \cdot 17 \\
0 \cdot 76 \\
0 \cdot 27\end{array}$ & $\begin{array}{l}0 \cdot 5 \\
0 \cdot 20 \\
0 \cdot 29 \\
0 \cdot 26 \\
0 \cdot 10\end{array}$ & $\begin{array}{l}\text { NS } \\
0 \cdot 01 \\
\text { NS } \\
\text { NS } \\
\text { NS }\end{array}$ \\
\hline
\end{tabular}

apoB = Apolipoprotein-B.

apoA-1 = Apolipoprotein-A1.
Table 2 Intake of nutrients in day and shift workers at baseline examination (two tailed test)

\begin{tabular}{|c|c|c|c|c|c|}
\hline & \multicolumn{2}{|c|}{$\begin{array}{l}\text { Day workers } \\
(n=13)\end{array}$} & \multicolumn{2}{|c|}{$\begin{array}{l}\text { Shift workers } \\
(n=12)\end{array}$} & \multirow[b]{2}{*}{$p$} \\
\hline & Mean & $S D^{\prime}$ & Mean & $S D$ & \\
\hline $\begin{array}{l}\text { Energy (kcal) } \\
\text { Protein (g) } \\
\text { Fat (g) } \\
\text { Carbohydrate (g) } \\
\text { Retinolekv (mg) } \\
\text { Vitamin } \mathbf{B}_{6} \\
\text { Vitamin } \mathbf{B}_{12}(\mu \mathbf{g}) \\
\text { Vitamin C (mg) } \\
\text { Vitamin D }(\mu \mathbf{g}) \\
\text { Calcium (mg) } \\
\text { Iron (mg) } \\
\text { Magnesium (mg) } \\
\text { Zinc (mg) } \\
\text { Phosphorus (mg) } \\
\text { Cholesterol (g) } \\
\text { Saccharose (g) } \\
\text { Fibres (g) } \\
\text { P/S-ratio }\end{array}$ & $\begin{array}{c}2762 \\
97 \\
119 \\
299 \\
1 \cdot 4 \\
2 \cdot 3 \\
8 \cdot 1 \\
85 \\
6 \cdot 9 \\
1273 \\
19 \\
376 \\
11 \cdot 3 \\
1687 \\
0 \cdot 42 \\
58 \\
16 \cdot 6 \\
0 \cdot 36\end{array}$ & $\begin{array}{c}381 \\
13 \\
18 \\
77 \\
1 \cdot 1 \\
0 \cdot 3 \\
4 \cdot 5 \\
32 \\
2 \cdot 7 \\
377 \\
1 \cdot 8 \\
64 \\
2 \cdot 1 \\
296 \\
0 \cdot 11 \\
42 \\
3 \cdot 0 \\
0.08\end{array}$ & $\begin{array}{c}2563 \\
92 \\
115 \\
271 \\
1 \cdot 3 \\
1 \cdot 9 \\
8 \cdot 3 \\
45 \\
6 \cdot 2 \\
1355 \\
18 \\
320 \\
10 \cdot 4 \\
1604 \\
0 \cdot 36 \\
50 \\
15 \cdot 1 \\
0 \cdot 40\end{array}$ & $\begin{array}{c}567 \\
20 \\
35 \\
68 \\
1 \cdot 2 \\
0 \cdot 5 \\
4 \cdot 2 \\
25 \\
3 \cdot 0 \\
390 \\
3 \cdot 3 \\
61 \\
2 \cdot 5 \\
367 \\
0 \cdot 14 \\
24 \\
3 \cdot 2 \\
0.08\end{array}$ & $\begin{array}{l}\text { NS } \\
\text { NS } \\
\text { NS } \\
\text { NS } \\
\text { NS } \\
0 \cdot 05 \\
\text { NS } \\
0.001 \\
\text { NS } \\
\text { NS } \\
\text { NS } \\
0.05 \\
\text { NS } \\
\text { NS } \\
\text { NS } \\
\text { NS } \\
\text { NS } \\
\text { NS }\end{array}$ \\
\hline
\end{tabular}

paring the two groups the difference in change of apoB/apoA-1 was reduced to an insignificant value $(\mathrm{p}=0.07)$.

The shift workers significantly reduced their intake of dietary fibre through a diminished intake of vegetables and potatoes. Their intake of soft drinks accounted for the increase in saccharose.

The change in fibre intake correlated inversely with the change in the ratio of apoB to apoA-1 $(r=-0.43, p=0.05$, see table 4).

No significant change in smoking behaviour was shown. The systolic blood pressure decreased significantly in both groups. An insignificant increase in diastolic blood pressure was observed in both groups. The change in systolic blood pressure did not correlate significantly with changes in major nutrients. The change in diastolic blood pressure, however, correlated inversely with the change in the

Table 3 Changes in subject characteristics from baseline examination to follow up (one tailed $t$ test)

\begin{tabular}{|c|c|c|c|c|c|}
\hline & \multicolumn{2}{|c|}{ Day workers } & \multicolumn{2}{|c|}{ Shift workers } & \multirow{2}{*}{$\begin{array}{l}\text { Shift v } \\
\text { day } \\
\text { workers } \\
p\end{array}$} \\
\hline & $\begin{array}{l}\text { Change } \\
\%\end{array}$ & $p$ & $\begin{array}{l}\text { Change } \\
\%\end{array}$ & $p$ & \\
\hline $\begin{array}{l}\text { Intake of: } \\
\text { Protein } \\
\text { Fat } \\
\text { Phosphorus } \\
\text { Saccharose } \\
\text { Fibres } \\
\text { P/S-ratio } \\
\text { Systolic BP } \\
\text { Diastolic BP } \\
\text { Cholesterol } \\
\text { Triglycerides } \\
\text { apoB } \\
\text { apoA-1 } \\
\text { apoB/apoA-1 }\end{array}$ & $\begin{array}{r}-5 \\
-1 \\
-4 \\
-8 \\
1 \\
-\quad 2 \\
-5 \\
-\quad 1 \\
28 \\
1 \\
-\quad 2 \\
5\end{array}$ & $\begin{array}{l}\text { NS } \\
\text { NS } \\
\text { NS } \\
\text { NS } \\
\text { NS } \\
0 \cdot 04 \\
\text { NS } \\
\text { NS } \\
\text { NS } \\
\text { NS } \\
\text { NS } \\
\text { NS }\end{array}$ & $\begin{array}{r}-13 \\
-12 \\
-13 \\
45 \\
-19 \\
8 \\
-\quad 9 \\
4 \\
3 \\
25 \\
8 \\
3 \\
18\end{array}$ & $\begin{array}{l}0.04 \\
0.05 \\
0.04 \\
\text { NS } \\
0.03 \\
0.01 \\
0.02 \\
\text { NS } \\
\text { NS } \\
\text { NS } \\
0.03 \\
\text { NS } \\
0.001\end{array}$ & $\begin{array}{l}\text { NS } \\
\text { NS } \\
\text { NS } \\
0.07 \\
0.03 \\
\text { NS } \\
\text { NS } \\
\text { NS } \\
\text { NS } \\
\text { NS } \\
\text { NS } \\
\text { NS } \\
0.07\end{array}$ \\
\hline
\end{tabular}


Table 4 Pearson correlation coefficients between changes in nutrient intake and changes in apo $A-1, A p o B$, and the ratio of $a p o B$ to apo $A-1$

\begin{tabular}{llll}
\hline Dietary item & $a p o B$ & $a p o A-1$ & $a p o B / A p o A-1$ \\
\hline Energy & -0.09 & -0.02 & -0.05 \\
Protein & -0.08 & 0.03 & -0.09 \\
Carbohydrate & -0.11 & 0.01 & -0.14 \\
Fat & -0.01 & -0.08 & 0.17 \\
Fibres & -0.28 & 0.14 & $-0.43 \star$ \\
Saccharose & -0.07 & -0.04 & -0.07 \\
\hline
\end{tabular}

${ }^{\star} p=0.05$

intake of dietary fibres $(r=-0.35, p=0.04)$, carbohydrates $(r=-0.42, p=0.02)$, and protein $(\mathrm{r}=-0.34, \mathrm{p}=0.05)$.

\section{Discussion}

In this study a significant change in serum lipoproteins was shown in shift workers. ApoBlipoproteins increased and a small decrease in apoA-1 was observed. This resulted in a significant increase in the ratio of apoB to apoA-1.

Cholesterol is carried in blood plasma by several lipoproteins including LDL and HDL cholesterol. Epidemiological studies have shown that serumlipoprotein concentrations are strongly predictive of the risk of atherosclerotic heart disease..$^{15} 16$

LDL cholesterol is associated with risk of CHD, whereas HDL cholesterol has a protective effect. Apolipoprotein B (apoB) is the protein component in LDL lipoproteins and apolipoprotein $A(a p o A)$ is the protein component in HDL lipoproteins. Apolipoproteins subserve specific functions, which include binding and solubilisation of lipids and removal of cholesterol from cells. The ratio between apoB and apoA is probably the best discriminator of CHD. ${ }^{17-21}$

Although the serum values of lipoproteins in the present study were normal in all subjects, the changes in the lipoproteins in shift workers might influence the risk of coronary events.

Previous studies have shown disturbances of serum lipoproteins in shift workers. The Tromso heart study reported raised levels of serum triglycerides and total cholesterol in shift workers. In a cross sectional study of 601 male blue collar workers we showed that shiftworkers had significantly higher levels of serum triglycerides. ${ }^{7}$ Total cholesterol, however, did not differ comparing the two groups.

The eating habits of shift workers have been subject to much debate but so far few studies have inquired how dietary intake is modified by shiftwork, ${ }^{22}$ and there has been no study of the association between diet and serum lipoproteins in shift workers.

Our results are based on a small group of subjects and the associations are statistically weak. Our find- ings, however, suggest that lipoprotein disturbances among shift workers could be explained by dietary factors. Thus our results raise the possibility that association between shift work and CHD could be mediated, in part, by changes in nutrient intake due to shift work.

The study was supported by grants from the Swedish Work Environment Fund.

1 Alfredsson L, Karasek R, Theorell T. Myocardial infarction risk and psychosocial work environment. An analysis of the male Swedish working force. Soc Sci Med 1982;16:463-7.

2 Akerstedt T, Knutsson A, Alfredsson L, Theorell T. Shift work and cardiovascular disease. Scand $J$ Work Environ Health 1984;10:409-14.

3 Knutsson A, Akerstedt T, Jonsson B, Orth-Gomer K. Increased risk of ischaemic heart disease in shift workers. Lancet 1986;ii:89-92.

4 Koller M. Health risks related to shift work. Int Arch Occup Environ Health 1983;53:59-75.

5 Thelle DS, Forde OH, Try K, Lehmann EH. The Tromso heart study. Acta Med Scand 1976;200:107-18.

6 Orth-Gomer K. Intervention on coronary risk factors by adapting a shift work schedule to biological rhythmicity. Psychosom Med 1983;45:407-15.

7 Knutsson A, Ákerstedt T, Jonsson B. Prevalence of risk factors for coronary artery disease among day and shift workers. Scand J Work Environ Health 1988;14:317-21.

8 Boigne JM, Boigne N, Galacteros F, Nalpas B, Philippon C, Vivien C. Dosage des proteins par immunoprécipitation sur analyseur centrifuge Centrifichem. Ann Biol Clin 1977;35: 237-54.

9 Spencer $\dot{K}$, Price CP. Kinetic immunoturbidimetry: the estimation of albumin. Clin Chem Acta 1979;95:263-7.

10 Burke BS. The dietary history as a tool in research. J Am Diet Assoc 1947;23:1041-6.

11 Black AE. Pitfalls in dietary assessment. In: Howard AN, Baird IM, eds. Recent advances in clinical nutrition. London: John Libbey, 1981:11-8.

12 National Swedish Food Administration. Livsmedelstabeller (food composition tables). Helsingborg: Schmidts Boktryckeri AB, 1981.

13 Bingham SA, Cummings JH. Urine nitrogen as an independent validatory measure of dietary intake: a study of nitrogen balance in individuals consuming their normal diet. Am J Clin Nutr 1985;42:1276-89.

14 Isaksson B. Urinary nitrogen as a validity test in dietary surveys. Am J Clin Nutr 1980;30:4-6.

15 Keys A. Seven countries: death and coronary heart disease. Cambridge: Harvard University Press, 1980.

16 Dawber TR. The Framingham study: the epidemiology of atherosclerotic disease. Cambridge: Harvard University Press, 1980.

17 Avogaro P, Bittolo Bon G, Gazzolato G, Qunici GB. Are apolipoproteins better discriminators than lipids for atherosclerosis? Lancet 1979;i:901-3.

18 Brunzell JD, Sniderman AD, Albers JD, Kwiterovich PO. Apolipoproteins $\mathrm{B}$ and $\mathrm{A}-1$ and coronary artery disease in humans. Arteriosclerosis 1984;4:79-83.

19 De Backer G, Rossenaeu M, Deslypere JP. Discriminative value of lipids and apoproteins in coronary heart disease. Atherosclerosis 1982;42:197-203.

20 Kukita H, Hiwada K, Kokubu T. Serum apolipoprotein A1, A2 and $B$ levels and their discriminative values in relatives of patients with coronary artery disease. Atherosclerosis 1984;51:261-7.

21 Noma A, Yokosuka T, Kitamura K. Plasma lipids and apolipoproteins as discriminators for presence and severity of angiographically defined coronary artery disease. Atherosclerosis 1983;49:1-7.

22 Reinberg A, Migraine C, Apfelbaum M, et al. Circadian and ultradian rhythms in the feeding behaviour and nutrient intakes of oil refinery operators with shift work every 3-4 days. Diabete \& Metabolisme 1979;5:33-41.

Accepted 14 April 1989 